\title{
Genetic Variability and Heritability Studies of Mango Cultivars
}

\author{
D. Sridhar ${ }^{1 *}$, B. Ghosh ${ }^{1}$, S. Kundu ${ }^{1}$, Md. Abu Hasan ${ }^{1}$ and N.C. Das ${ }^{2}$ \\ ${ }^{1}$ Department of Fruit and Orchard Management, ${ }^{2}$ Department of Soil and Water \\ Conservation, Bidhan Chandra Krishi Viswavidyalaya, Mohanpur, Nadia, West Bengal, India \\ *Corresponding author
}

\section{A B S T R A C T}

\section{Keywords}

Mango, Genetic advance, Genotypic coefficient of variation, Phenotypic coefficient of variation, Heritability

\section{Article Info}

Accepted: 06 August 2018 Available Online: 10 September 2018
The present study was carried out to assess the genetic variability, heritability and genetic advance for different characters in 16 diverse cultivars of mango. The study was conducted at Regional Research Station, Gayeshpur during 2016 and 2018. Random sampling strategy was followed for collection of samples. All the characters showed very small difference between genotypic coefficient of variation $(\mathrm{GCV})$ and respective phenotypic coefficient of variation (PCV), indicated that all the characters were least affected by environment. The high phenotypic coefficient of variation and genotypic coefficient of variation were observed for petiole length, inflorescence width, fruit weight, pulp content, stone weight, seed width, seed weight, reducing sugars, non-reducing sugars, titratable acidity, TSS: acid ratio, ascorbic acid and yield. High heritability coupled with high genetic advance were observed for all characters studied indicating these characters are governed by additive gene action and phenotypic selection may be more fruitful. Hence, direct selection may be followed for the improvement of mango for these characters.

\section{Introduction}

Mango (Mangifera indica L.) is one of the choicest and admired fruit crops of the tropical and subtropical areas of the world. Its significance can easily be recognized by the fact that it is known as 'King of Fruits'. Utilization of germplasm with distinctive characteristics in breeding programmes desires precise information to develop new cultivars (Vasugi et al., 2012). India is the centre of origin for cultivated mango and is distributed in tropical and subtropical regions. Mango has been cultivated in India for more than 4000 years. Mango is native to India and occurs abundantly in forests and cultivated areas. Hence, it is difficult to differentiate true wild forms from cultivated ones. The crosspollination nature and a wide range of prevailing agro climatic conditions have contributed to its wide genetic diversity in India in mango (Mukherjee, 1972).

There are about 2000 varieties grown in India, out of which only a few happen to be of commercial importance and export potential. Mango is considered to be an allopolyploid, most probably amphidiploid and outbreeding 
species having chromosome number $2 n=40$ (Mukherjee, 1950). It is highly heterozygous as performance varies with the climate which resulted in a high level of genetic diversity. Further, confusion exists in the nomenclature of mangoes due to different local names for the same variety. Characterization and assessment of diversity is essential to utilize these unique cultivars in crop improvement programmes and also for better conservation of genetic resources, it especially benefits a plant breeder in choosing proper parental materials. To improve yield potentials in an existing crop, an understanding of the variability is necessary to formulate and accelerate breeding program. The genotypic and phenotypic coefficient of variation within a crop will facilitate in selection of superior genotypes which is proportional to the amount of genetic variability present and the extent to which the characters are inherited. Since, many economic traits are quantitative in nature and highly influenced by the environment, the progress of breeding is governed by the nature of genetic and nongenetic variations; it will be useful to partition the overall variability into its heritable and non-heritable components to know whether superiority of selection is inherited by the progenies. Effective selection of genotypes for desirable traits is determined by the estimates of heritability along with genetic advance. The progress in breeding programme depends on magnitude of genetic variability present in breeding material. Selection is also effective when there is high degree of genetic variability among the individuals in a population. Therefore, the present investigation was undertaken to estimate the variability, heritability and genetic advance among different traits in mango cultivars.

\section{Materials and Methods}

A well planned germplasm collection survey based on diversity richness was conducted at
Regional Research Station, Gayeshpur during 2016 and 2018. Random sampling strategy was followed for collection of samples. Three plants in each cultivar were taken as sample size. The experimental material consists of 16 indigenous mango cultivars such as Chatterjee, Gulab Khas, Ranipasand, Sarikhas, Himsagar, Banganpalli, Langra, Fazli, Gopal Bhog, Lakhan Bhog, Kancha Mitha, Kanchan Kosa, Kamala Bhog, Gopi Bhog, Madhu Chuski and Khota Lagga were selected for the study.

Ten fruits of each cultivar were taken per replication for evaluating fruit morphological and bio-chemical characters. Genotypic and phenotypic coefficients of variation were computed according to Burton (1952) based on the estimate of genotypic and phenotypic variance.

Heritability in broad sense refers to the proportion of genetic variance to the total observed variance in the population. It has been estimated as per the formula given by Lush (1940). Genetic advance as per cent mean was worked out for each character adopting the formula given by Johnson et al., (1955b).

\section{Results and Discussion}

In the present investigation, phenotypic coefficient of variation (PCV) was greater than the corresponding genotypic coefficient of variation (GCV) for all the characters indicating the importance of environment in expression of characters. However, the differences between the GCV and PCV for all the characters were narrow suggesting that the characters were less affected by environment. The range of PCV and GCV were classified as suggested by Sivasubramanian and Madhavamenon (1973) i.e., 0-10\% as low, $10-20 \%$ as moderate and more than $20 \%$ as high. 
Highest estimates of genotypic variance was observed for petiole length, inflorescence width, fruit weight, pulp content, stone weight, seed width, seed weight, reducing sugars, nonreducing sugars, titratable acidity, TSS: acid ratio, ascorbic acid and yield (Table 1 and 2). Highest estimates of phenotypic variance was observed for petiole length, inflorescence width, fruit length, fruit diameter, fruit weight, pulp content, stone weight, seed width, seed weight, reducing sugars, non-reducing sugars, titratable acidity, TSS: acid ratio, ascorbic acid and yield/plant characters. The differences between values of PCV and GCV were less for tree height, pulp content, stone length and stone weight, indicating that these characters were largely under genetic control and environment had least influence on the expression of these traits. Similar results conformity with patel et al., (2016), Himabindu et al., (2016) and Galal et al., (2017) findings in mango.
The broad sense heritability is the relative magnitude of genotypic and phenotypic variances for the traits and it is used as a predictive role in selection procedures. High heritability was recorded for majority of the characters viz., tree height (99.51), inflorescence length (95.36), inflorescence width (95.32), fruit diameter (94.53), fruit weight (91.81), fruit skin thickness (93.16), pulp content (99.07), stone length (97.31), stone weight (96.72), seed width (95.46), seed weight (97.52), TSS (94.06), reducing sugars (93.61), ascorbic acid (94.88) and yield/plant (96.59).High heritability generally indicate that the environment effect was very low and enables the breeder to select plants on the basis of the phenotypic expression.

Therefore, selection of these characters would be feasible for mango improvement. Similar results were observed by Majumder et al., (2012) and Galal et al., (2017).

Table.1 Estimates of variability and genetic parameters for morphological characters of mango

\begin{tabular}{|c|c|c|c|c|c|c|c|}
\hline \multirow[t]{2}{*}{ Characters } & \multirow[t]{2}{*}{ Mean } & \multicolumn{2}{|c|}{ Range } & \multirow{2}{*}{$\begin{array}{l}\text { Phenotypic } \\
\text { coefficient } \\
\text { of variation }\end{array}$} & \multirow{2}{*}{$\begin{array}{l}\text { Genotypic } \\
\text { coefficient } \\
\text { of variation }\end{array}$} & \multirow{2}{*}{$\begin{array}{c}\text { Heritability } \\
\text { (broad sense) } \\
(\%)\end{array}$} & \multirow{2}{*}{$\begin{array}{c}\text { Genetic } \\
\text { advance as per } \\
\text { cent mean }(\%)\end{array}$} \\
\hline & & Min & Max & & & & \\
\hline Tree height & 10.25 & 6.60 & 13.02 & 17.41 & 17.37 & 99.51 & 45.74 \\
\hline Leaf blade length & 22.88 & 17.88 & 29.52 & 16.03 & 14.24 & 78.99 & 33.42 \\
\hline Leaf blade width & 6.28 & 4.68 & 8.35 & 18.04 & 15.61 & 74.90 & 35.66 \\
\hline Petiole length & 3.41 & 1.79 & 5.37 & 37.94 & 30.31 & 63.81 & 63.91 \\
\hline Inflorescence length & 32.57 & 23.56 & 45.50 & 19.95 & 19.49 & 95.36 & 50.23 \\
\hline Inflorescence width & 21.22 & 11.18 & 31.74 & 28.42 & 27.74 & 95.32 & 71.51 \\
\hline Fruit length & 9.33 & 6.30 & 12.96 & 20.17 & 18.30 & 82.32 & 43.84 \\
\hline Fruit diameter & 6.05 & 4.03 & 7.92 & 20.03 & 19.47 & 94.53 & 49.98 \\
\hline Fruit weight & 220.12 & 107.24 & 395.79 & 40.81 & 39.10 & 91.81 & 98.90 \\
\hline Fruit skin thickness & 1.06 & 0.76 & 1.38 & 16.35 & 15.78 & 93.16 & 40.22 \\
\hline Pulp content & 1.82 & 1.16 & 3.17 & 29.70 & 29.56 & 99.07 & 77.67 \\
\hline Stone length & 7.47 & 5.53 & 9.18 & 14.05 & 13.86 & 97.31 & 36.09 \\
\hline Stone width & 3.64 & 3.00 & 4.47 & 11.82 & 11.20 & 89.81 & 28.03 \\
\hline Stone thickness & 2.10 & 1.59 & 2.42 & 13.20 & 11.85 & 80.68 & 28.11 \\
\hline Stone weight & 32.17 & 21.12 & 46.40 & 21.97 & 21.60 & 96.72 & 56.09 \\
\hline Seed length & 5.75 & 4.05 & 7.30 & 14.90 & 12.84 & 74.28 & 29.23 \\
\hline Seed width & 2.87 & 1.89 & 3.29 & 25.08 & 24.50 & 95.46 & 63.19 \\
\hline Seed weight & 16.46 & 6.05 & 22.85 & 34.65 & 34.22 & 97.52 & 89.22 \\
\hline Yield/plant & 1.57 & 0.85 & 2.91 & 45.70 & 44.92 & 96.59 & 116.54 \\
\hline
\end{tabular}

Note: PCV, GCV and Genetic advance as per cent mean: Low =0-10\%; Medium = 10-20\%; High = 20\% above Heritability: Low $=$ Less than 30\%; Medium $=30-60 \%$; High $=$ More than $60 \%$ 
Table.2 Estimates of variability and genetic parameters for fruit bio-chemical characters of mango

\begin{tabular}{|c|c|c|c|c|c|c|c|}
\hline \multirow[t]{2}{*}{ Characters } & \multirow[t]{2}{*}{ Mean } & \multicolumn{2}{|c|}{ Range } & \multirow{2}{*}{$\begin{array}{l}\text { Phenotypic } \\
\text { coefficient } \\
\text { of } \\
\text { variation }\end{array}$} & \multirow{2}{*}{$\begin{array}{c}\text { Genotypic } \\
\text { coefficient } \\
\text { of } \\
\text { variation }\end{array}$} & \multirow{2}{*}{$\begin{array}{l}\text { Heritability } \\
\text { (broad } \\
\text { sense) }(\%)\end{array}$} & \multirow{2}{*}{$\begin{array}{c}\text { Genetic } \\
\text { advance } \\
\text { as per } \\
\text { cent } \\
\text { mean }(\%)\end{array}$} \\
\hline & & Min & Max & & & & \\
\hline TSS & 17.85 & 14.79 & 20.87 & 17.22 & 16.70 & 94.06 & 42.76 \\
\hline Total sugars & 12.16 & 8.58 & 14.57 & 14.65 & 12.67 & 74.79 & 28.93 \\
\hline Reducing sugars & 3.98 & 2.48 & 5.74 & 23.41 & 22.65 & 93.61 & 57.87 \\
\hline $\begin{array}{l}\text { Non-reducing } \\
\text { Sugars } \\
\end{array}$ & 8.18 & 5.41 & 11.54 & 24.87 & 22.21 & 79.73 & 52.35 \\
\hline Titratable acidity & 0.34 & 0.07 & 0.92 & 83.93 & 71.42 & 72.41 & 160.44 \\
\hline TSS: acid ratio & 83.47 & 15.64 & 191.12 & 66.50 & 57.37 & 74.43 & 130.67 \\
\hline Ascorbic acid & 32.80 & 23.85 & 68.36 & 34.93 & 34.02 & 94.88 & 87.50 \\
\hline
\end{tabular}

Note: PCV, GCV and Genetic advance as per cent mean: Low $=0-10 \%$; Medium $=10-20 \%$; High $=20 \%$ above Heritability: Low $=$ Less than 30\%; Medium $=30-60 \%$; High $=$ More than $60 \%$

Genetic advance as per cent of mean was recorded highest for all the characters. Among the characters fruit weight (98.90), titratable acidity (160.44), TSS: acid ratio (130.67) and yield/plant (116.54) characters were recorded highest comparing to all characters. It also revealed high degree of variation among the cultivars.

High heritability do not always indicate high genetic gain, heritability with genetic advance considered together should be used in predicting the ultimate effect for selecting superior genotypes. High estimates of heritability estimates coupled with high genetic advance were obtained for all traits and it indicated the presence of additive gene action in the inheritance of these traits and simple selection would be highly rewarding for improving these characters. Rajan et al., (2009), Patel et al., (2016), Himabindu et al., (2016) and Galal et al., (2017) reported similar experimental findings in mango.

From the results presented in the afore said paragraphs it was evident that the characters namely, inflorescence length, inflorescence width, fruit diameter, fruit length, pulp content, stone weight, seed width, reducing sugars, non-reducing sugars, TSS: acid ratio, ascorbic acid and yield/plant had recorded higher estimates for phenotypic coefficient of variation, genotypic coefficient of variation, genetic advance as per cent mean and heritability its indicated that the presence of additive gene action in the inheritance of this trait and simple selection would be highly rewarding for improving these characters.

\section{References}

Burton, G.N. 1952. Quantitative Inheritance in Grasses. Proceedings of Sixth International Grassland Congress. 1: 277-283.

Galal, O.A, Galal, H.A. and Aboulila. A.A. 2017. Genetic variability and molecular characterization of some local and imported mango cultivars In Egypt. Egypt Journal of Genetics and Cytology. 46: 121-138.

Himabindu, A, Srihari, D, Rajasekhar, M, Sudhavani, V, Subbarammamma, P. and Uma Krishna, K. 2016. Genetic 
variability and heritability studies of mango cultivars. International Journal of Science and Nature. 7(1): 168-172.

Johnson, H.W, Robinson, H.F. and Comstock, R.E. 1955b. Genotypic and phenotypic correlations in soybean and their implication in selection. Agronomy Journal. 47: 477-483.

Lush, J. L. 1940. Intra-sire correlation on regression offspring on dams as a method of estimating heritability of characters. Proceedings of American Society of Animal Production. 33: 292301.

Majumder, D.A.N, Hassan, L, Rahim, M.A. and Kabir, M. A.2012. Correlation and path coefficient analysis of mango (Mangifera indica $\quad$ L.).Bangladesh Journal of Agricultural Research. 37(3): 493-503.

Mukherjee, S.K. 1950. Mango: Its allopolyploid nature. Nature. 166: 196197.
Mukherjee, S.K. 1972. Origin of mango. Economic Botany. 26: 260-264.

Patel, M.C, Patel, D.A, Patel, K.V, Soni, N.V, Satodiya, B.N. and Jadav, R.G. 2016. Genetic variability and correlation studies for fruit yield and quality parameters in mango (Mangifera indica L.). Green Farming. 7(3): 706-709.

Rajan, S, Yadava, L.P. Kumar, R. and Sexena, S. K. 2009. Genetic divergence in mango varieties and possible use in breeding. Indian Journal of Horticulture.66: (1) 7-12.

Sivasubramanian, V. and Madhavamenon, P. 1973. Path analysis for yield and yield components of rice. Madras Agricultural Journal. 60:1217-1221.

Vasugi, C, Dinesh, M.R, Sekhar, K, Shivashankara, K.S, Padmakar, B. and Ravishankar, K.V. 2012. Genetic diversity in unique indigenous mango accessions (Appemidi) of the Western Ghats for certain fruit characteristics. Current Science. 103(2): 199-207.

\section{How to cite this article:}

Sridhar, D., B. Ghosh, S. Kundu, Md. Abu Hasan and Das, N.C. 2018. Genetic Variability and Heritability Studies of Mango Cultivars. Int.J.Curr.Microbiol.App.Sci. 7(09): 752-756. doi: https://doi.org/10.20546/ijcmas.2018.709.090 